\title{
Investigating Determinants that Affect Job and Life Dissatisfaction: The Case of Relocation
}

\author{
Yoojeong KIM*, Yooncheong CHO**
}

Received: January 15, 2020 Revised: February 28, 2020 Accepted: March 05, 2020.

\begin{abstract}
Purpose: Geographical relocation has been conducted to alleviate overcrowding and to support balanced regional development in many countries. Previous studies have seldom examined the effectiveness of relocation on job and life dissatisfaction, particularly in the public sector. The purpose of this study is to investigate the determinants of relocation on job and life dissatisfaction. Proposed research questions include the following: i) do working conditions in the new workplace and interactivity affect job dissatisfaction? ii) do social infrastructure and social activity in the new location affect life dissatisfaction? and iii) is there a relationship between job and life dissatisfaction? Research Design, data, and methodology: The study collected data via an online survey and applied statistical analyses such as factor analysis, regression, and ANOVA. Results: The results of this study found that proposed determinants excluding mobility inefficiency and decision-making affect job and life dissatisfaction. The results also showed that there are relationships between job and life dissatisfaction. Conclusions: The results of this study provide both managerial and policy implications of relocation for the public sector. The results of this study implied that better policy should be designed to increase job and life satisfaction that also accounts for the realities of relocation.
\end{abstract}

Keywords: Relocation, Job dissatisfaction, Life dissatisfaction

JEL Classification Code: J28, I38, M10

\section{Introduction}

Governments push to reform and make changes in organizational structure, processes, and culture in a way that seeks greater efficiency. Halachmi (1997) argued that government has to use changes in public sector organizations and public services, in order to drive changes in national economies by changing the nature of government itself. Reform driven by government is carried out to enhance the performance of the organization and to achieve national policy goals such as the balanced development of the whole nation. In the course of this process, geographical relocation of public organizations has often been a strategy adopted by the nation's policymakers. Rossman (2017) pointed out that strengthening political

*Graduate, KDI School of Public Policy and Management, Korea. Email: kimyj823@naver.com

${ }^{* *}$ Corresponding Author: Professor, KDI School of Public Policy and Management, Korea. Email: ycho@kdischool.ac.kr

(c) Copyright: Korean Distribution Science Association (KODISA)

This is an Open Access article distributed under the terms of the Creative Commons Attribution NonCommercial License (https://creativecommons.org/licenses/by-nc/4.0/) which permits unrestricted noncommercial use, distribution, and reproduction in any medium, provided the original work is properly cited. power could result in more decisive parameters for capital city relocations.

Previous researchers (e.g., Brett \& Reilly, 1988; Eby \& Russell, 2000; Turban, Campion, \& Eyring, 1992) stated that relocation in general has focused almost exclusively on predictors of relocation decision-making or willingness to move rather than the consequences of relocation for postmove inclinations and attitudes. More recently, a piecemeal dispersal of the public sector can be seen in some countries, including Mexico, Norway, and Denmark (Economist, 2019). In South Korea, the government has actively promoted measures that disperse the central government and public institutions to newly built cities in order to resolve overcrowding in the Seoul metropolitan area and support more balanced national development.

The purposes of relocation in the public sector include balanced development and the success of the policy depends settling the employees and their families, improving performance of the relocated organizations, and playing a leading role in developing regional cities. The extent to which relocation increases job and life satisfaction is also a crucial issue. Relocated organizations have 
implemented various policies to establish better environments in which to work and live. Most of the past studies on geographical relocation of workplaces address intention to relocate and job satisfaction of employees in private companies (e.g., Cotton \& Majchrzak, 1990), while there is a lack of research in the public sector. A few researchers (e.g., Fox \& Krausz, 1987) explore the impact of relocation on the employees of governmental organizations, while the scope of research is limited to job satisfaction rather than life satisfaction. To fill this gap, the present study focuses on factors that affect job and life satisfaction of employees whose workplace has been moved to a new planned city.

Based on the considerations above, this study investigated factors that affect job dissatisfaction such as working conditions and interactivity in the workplace and factors that affect life satisfaction such as social infrastructure and social activity. Previous studies on relocation examined issues on regional development, economic ripple effect, and decentralization, particularly in other countries rather than Korea (Kim, 2005). Previous studies rarely examined how workers who settled in relocated areas perceive job and life dissatisfaction. This study also examined causal relationships of job and life satisfaction due to relocation. While past studies mostly addressed pre-move attitude toward relocation and turnover intention in the private sector, this study highlights postmove attitudes and the psychological states of relocation particularly in the public sector. Further, this study contributes to finding implications for relocation policy when it comes to a dearth of research on relocation in the public sector.

\section{Literature Review}

\subsection{Relocation}

Geological relocation policies of public institutions are often found in advanced countries and have attempted mainly to curb population concentration in large cities and promote balanced regional development (Ju, 2003). The relocation policy for public institutions was initiated in the U.K to alleviate overcrowding and fiscal deficits in London and revitalize the economy in underdeveloped regions (Bae, 2005). In France, about 25,000 people were relocated from 1960 to 1990 to ease overpopulation in the Paris area, and about 270 institutions and 34,000 people were distributed across eight regional cities and underdeveloped areas seven times from 1991 to 2003 (Ju, 2003). In order to resolve overcrowding in the Tokyo area, Japan decided to relocate at a ministerial meeting in January 1988 and relocated 59 national agencies by $2002(\mathrm{Ju}, 2003)$.
The Korean government has actively promoted measures that disperse the central government to newly built cities in order to resolve overcrowding in the Seoul metropolitan area and support balanced regional development. The effectiveness of the relocation is being tested in various ways, and some have begun to address the need for a second relocation policy. Proponents argue that it is necessary to reduce the polarization of provinces, while opponents demonstrate various issues, such as administrative inefficiency.

Park and Kim (2002) proposed different types of relocation for the administrative capital and public institutions; i) the first is to build or transfer collectively the functions of the central government to a specific area; ii) the second is the dispersion of government agencies by relocating them to different cities; and iii) the relocation of public institutions other than government agencies from the existing capital to another city. The second and third are often used to alleviate the concentration of the large cities and to resolve regional imbalances.

\subsection{Job Satisfaction}

Wright and Davis (2003) pointed out that job satisfaction is the congruence between what workers expect from their job and what workers think they actually get. Gilmer (1971) stated that psychological and logical disposition of employees toward their jobs result in a positive or negative attitude toward their jobs. Previous studies (Baldwin \& Farley, 1991; Rainey, 1983) found that public sector workers were less likely to be satisfied with their jobs than private sector workers. In contrast, other scholars (DeSantis \& Durst, 1996; Steel \& Warner, 1990; Wang, Yang, \& Wang, 2012) suggested that the job satisfaction level of public workers is often higher than that of private sector workers.

Numerous studies (Naumann, 1993) on job satisfaction make the assumption that satisfied employees make greater contributions to organizational performance and long-term goals, and dissatisfied employees are less likely to be better workers in terms of organizational effectiveness. Previous studies also indicated that higher job satisfaction is closely related to higher job performance (Judge, Thoresen, Bono, \& Patton, 2001), while lower job satisfaction leads to a higher probability of turnover (Clark, Georgellis, \& Sanfey, 1998). Given the fact that turnover indicates the dissatisfaction of employees, job satisfaction has been treated as a subject of organizational psychology in previous studies pointing out that job satisfaction and life satisfaction are correlated, and that they directly influence the psychological and physical health of employees (Filiz, 2014). 


\subsection{Life Satisfaction}

Filiz (2014) suggested that satisfaction means meeting expectations, wishes, needs, and desires. Previous researches addressed the importance of satisfaction (Kim, 2019; Nguyen \& Khoa, 2019). Diener (1994) argued that life satisfaction is people's assessment of the extent to which they are satisfied with their whole life. Life satisfaction as a cognitive judgment of an individual's life is commonly used in estimating subjective well-being that shows the extent to which people appreciate their lives (Wong, Wong, \& Mok, 2006). Fahey and Smyth (2004) indicated that the measure of life satisfaction, happiness and other facets of subjective well-being have been restrictively accepted as a tool for the social-scientific analysis of human welfare, but are still almost unique from a psychological and sociological perspective. Quality of life is often seen as material well-being, which means livability and standard of living, while it can also be defined in subjective terms such as self-reported life satisfaction (Okulicz-Kozaryn, 2013; Veenhoven, 1996). Lyubomirsky, King, and Diener (2005) stated that livability is a measure of objective quality of life and is important for business because happy people are better workers. For government, livability is important because livable cities attract competitive business and labor, and regional development depends on business activation. (Economist, 2011).

\subsection{Satisfaction and Relocation}

A number of studies have indicated that relocation can cause a threat to security concerning losing control over the properties of life (Brett, 1980; Thompson, 1981). Change and alteration tend to trigger symptoms of stress due to both the serious decisions required (Janis \& Mann, 1977) and the handling and familiarization (Dohrenwend \& Dohrenwend, 1974; Feldman \& Brett, 1983). Fox and Krausz (1987) argued that stress level increases because of unpredictability and insecurity related to course of relocation. Eby and Dematteo (2000) argued that intention to relocate has an effect on post-move work attitudes and inclination to change jobs. Cotton and Tuttle (1986) stated that turnover is associated with job dissatisfaction. Summers and Holcombe (1990) pointed out that individuals perceive relocation decisions as involuntary and might feel resentment and perceive their organization as less helpful to them.

\section{Hypothesis Development}

The study investigates the determinants of job dissatisfaction and life dissatisfaction of workers in the public sector after relocation and causal relationships between job and life satisfaction. This study classified effects of determinants on job and life dissatisfaction. For job dissatisfaction, effects of working conditions and interactivity are applied. Perceived job compatibilities are considered as working condition variables, while building relationships and trust are considered as interactivity variables. For life dissatisfaction, perceived social infrastructure and social activity are proposed as determinants.

\subsection{Working Conditions}

\subsubsection{Mobility Inefficiency}

Since relocation, many employees have experienced long-distance commuting and business travel. Psychological and sociological research has traditionally focused on stress as a phenomenon in the world of work and society (Gottholmseder, Nowotny, Pruckner, \& Theurl, 2009). Many studies show that long commutes and congestion can cause stress that results in organizational costs such as reduced labor productivity and higher job turnover and absenteeism (Wener, Evans, Phillips, \& Nadler, 2003; Schaeffer, Street, Singer, \& Baum, 1988). In the case of Korea, the plan to relocate public institution and government did not include major agencies such as the national assembly, and government employees are often facing work-related travel to have meetings, while frequent business trips can generate employee fatigue and stress. This study hypothesizes the effects of mobility inefficiency on job dissatisfaction.

H1a: Mobility inefficiency affects job dissatisfaction after relocation.

\subsubsection{Decision-making Process}

Kim, and Lee (2017) argued that with geographical relocation, the quality of policy and the processes of decision-making have changed and indicated that concerns have been raised about the deterioration in policy quality due to frequent business trips and weakened interactions. Furthermore, studies also point out that this phenomenon can be serious for non-standard and non-programmed decisions that require a long-term view and macro perspective (Kim, \& Lee, 2017). For instance, the quality of decision making could be lowered due to a lack of in-depth discussion. Even though organizations encourage using information and communication technology such as mobile messenger and video conferencing other than business trip for face-to-face meetings, it has not been verified whether it is effective enough to replace face-to-face meetings. This study hypothesizes the effects of decision-making on job dissatisfaction. 
H1b: Decision-making process affects job dissatisfaction after relocation.

\subsubsection{Work System}

The growing interest of individuals in quality of life, including quality of work life, is reflected in the growing social concern of organizations, and becomes significant for organizational behavior and the management of organizations (Wiggins, \& Steade, 1976). Especially, since the 1970s, new forms of flexible working-time patterns such as flexi-time systems or time off in lieu of overtime, have been discussed intensively in the literature (Krings, Nierling, Pedaci, \& Piersanti, 2009). This concept is based on industrial democracy and the rights of citizenship, including free speech in the workplace and emerging concepts of social justice (Wiggins \& Steade, 1976). Greater freedom of action has been recognized as a prerequisite for satisfactory working conditions of the bureaucratic system in the field of humanistic organizational psychology (Matiaske, \& Grözinger, 2011). However, relocation might negatively affect work system due to reasons such as less flexible work scheduling and reduced interrelationships of workers. Negative work system might also cause less opportunity to spend time with family and friends. This study hypothesized effects of work systems on job dissatisfaction.

H1c: Negative perception on work system affects job dissatisfaction after relocation.

\subsubsection{Self-Development Opportunity}

London and Smither (1999) stated that self-development means seeking and using feedback, setting development goals, engaging in development

activities, and tracking progress on one's own. Previous studies (e.g. Carless 2005; Edwards, 1991) focus on vocational compatibility regarding employee knowledge, demands of an employee for skills, and ability to carry out the job. Edwards (1991) stated that i) if a person has relevant knowledge, skill, and ability to accomplish his or her job, it is more likely that a person is satisfied with the job; and ii) if a person's needs, desires or preferences are met by the job, then it is likely they have good compatibility with their job. As such, job satisfaction is associated with the opportunity to complete tasks through the exercise of an individual's knowledge and abilities. However, this study posits that relocation causes negative perception on self-development opportunities. This study hypothesized the effects of self-development opportunities on job dissatisfaction.

H1d: Negative perception on self-development opportunities affect job dissatisfaction after relocation.

\subsection{Interactivity}

Interpersonal compatibility between individuals and their work group members is meaningful (Kristof, 1996; Werbel \& Johnson, 2001). Job satisfaction focuses on the work environment in specific areas of a job where an individual carries out their tasks (Mowday, Porter, \& Steers, 1982). Value congruence (teamwork) between coworkers is assumed to be a meaningful factor in organizational performance in the public sector (Brewer \& Selden, 2000) and is associated with job satisfaction and work attendance (Adkins, Ravlin, \& Meglino, 1996). According to Spector and Jones (2004), trust in individuals is an expectation or belief that actions from another party will be motivated by good intentions. Chen, Hsieh, and Chen (2014) discussed that in the case of public managers, trust in colleagues can reinforce their trust in citizens through a spillover effect and accordingly enhances their public service motivation. This study hypothesized effects of building relationships and trust in the workplace on job dissatisfaction.

H2a: Lowered building relationships in the workplace affects job dissatisfaction after relocation.

H2b: Lowered building trust in the workplace affects job dissatisfaction after relocation.

\subsection{Social Infrastructure}

Previous researches (e.g., Kim \& Kim, 2012; Ott, 2011; Basley \& Coate, 1997) found that good governance is crucial in reducing inequality, improving welfare and people's quality of life, and enhancing their life satisfaction through provision of public goods. In fact, the government designed relocation policy in ways that can provide a living environment that approximates that of a large city where people lived before moving. Thus, the current study hypothesized that social infrastructure aspects such as public transportation system and schools would be crucial and meaningful predictors of life satisfaction. This study specially posed two hypotheses by dividing social infrastructure into two categories: amenities for mass public such as public transportation and shopping centers, and facilities directly related to upbringing youth.

Previous studies (Fox \& Krausz, 1987; Fisher \& Shaw, 1994) found that the willingness to move with their families was related to available infrastructure. Fox and Krausz (1987) pointed out that willingness to move is strongly related to family members' attitude to relocation. For example, youth could be influential to relocation decisionmaking. This is also supported by Kolar's research (1977) focusing on spouses' attitudes as a crucial factor in satisfaction after relocation. On the other hand, government has made efforts to make new cities good places to live by 
providing various amenities. If they have relocated to a new planned city, various measures are taken to make the city a better place to live. This study hypothesized effects of social infrastructure for mass public and youth on life dissatisfaction.

H3a: Lower level of social infrastructure for mass public in new location affects life dissatisfaction.

H3b: Lower level of social infrastructure for youth in new location affects life dissatisfaction.

\subsection{Social Activity}

Many previous researches (e.g. Guarnieri, Smorti, \& Tani, 2015; Lim \& Putnam, 2010; Sirgy \& Cornwell, 2002) show that interaction with other people is positively related to life satisfaction. A number of studies demonstrate that balancing autonomy and relevance in terms of establishing relationships with major social partners seems crucial when fundamental indicators of subjective well-being are developed (Ma \& Huebner, 2008; Nickerson \& Nagle, 2005; Wei, Liao, Ku, \& Shaffer, 2011). Some researchers (e.g. Paterson, Field, \& Pryor, 1994; Terry \& Huebner, 1995) claim that attachment relationships with parents and peers are important indicators of life satisfaction and well-being. Numerous studies regard social networks created in religious groups as a great source of well-being (e.g., Krause, 2008; Inglehart, 2010). This study hypothesized the effects of social activity on life dissatisfaction.

H4: Lowered social activity in new location affects life dissatisfaction.

\subsection{Job and Life Dissatisfaction}

The effects of work and job satisfaction on life satisfaction have been addressed in previous literature to different extents (Bass \& Bass, 1976; Biderman \& Drury, 1976) Matiaske and Grozinger (2011) viewed job satisfaction as an indicator of an individual's welfare in measuring quality of life beyond the economic social product. Wiggins and Steade (1976) pointed out that quality of life depends on an acceptable overall life pattern that includes increased satisfaction in the job segment. For those who move to new planned cities and need to adjust to unfamiliar environments, settlement conditions have an especially great impact on their life satisfaction. Fox and Krausz (1987) stated that family members' attitude toward moving is a crucial element to relocation decision-making. This study hypothesized effects of job dissatisfaction on life dissatisfaction and vice versa.

H5a: Job dissatisfaction negatively affects life dissatisfaction.
H5b: Life dissatisfaction negatively affects job dissatisfaction.

\section{Methodology}

The purpose of this study is to investigate determinants of job and life dissatisfaction after relocation. This study focused on employees of public organizations who have moved to Sejong City, including government officials and employees, since 2012. Sejong City is a new administrative capital located 100 kilometer away from Seoul and consists of modern buildings, providing quality work environment. Thus, employees should adjust to changed workplace circumstances and are required to move to Sejong City and its surrounding region.

The study collected data via an online survey. The online survey was conducted based on the platform called Qualtrics, which creates an online link so that the questionnaire can be easily distributed through such means as messengers or SNS. The survey involved 109 participants randomly selected from employees working in Sejong. The survey was distributed to 135 people, and a total of 109 respondents completed the survey, yielding a response rate of 80.7 percent. The survey comprises 38 questions regarding work conditions, living environment, demographic information, and so on. A 5-point Likert scale was applied with $1=$ Strongly Disagree and $5=$ Strongly Agree. To measure the reliability of variables for a multiitem scale, Cronbach's alpha was applied. Quantitative methods such as factor analyses and regression analyses (both simple and multiple regression) were applied to measure the effects of determinants on job and life dissatisfaction. Furthermore, additional findings included the results of Chi-square, $t$-test, and the analysis of variance (ANOVA).

\section{Data Analysis}

A total of 109 employees working in Sejong responded to the survey. Table 1 summarized demographics.

This study analyzed mean values for proposed variables. Mean values of variables of working conditions, interactivity, and social activity were between 3 and 4, while mean values of social infrastructure were between 4 and 5. Therefore, the results showed that respondents answered more negatively with social infrastructures for mass public.

The study applied factor analysis to check the validity of the major construct. Using principal components analyses as the extraction method and Varimax rotation methods with Kaiser Normalization, the most relevant data 
emerged. The results of the factor analysis successfully represented the major constructs with Eigen values greater than 1.00. Tables 2 - 5 summarize the results of factor analyses.

Table 1: Summary of Demographics

\begin{tabular}{|c|c|c|}
\hline & Classification & \% \\
\hline \multirow{2}{*}{ Gender } & Female & 52.2 \\
& Male & 47.8 \\
\hline \multirow{2}{*}{ Marital status } & Married & 67.9 \\
& Unmarried & 32.1 \\
\hline \multirow{3}{*}{ Age } & 21-29 years old & 9.2 \\
& 30-39 years old & 25.7 \\
& 40-49 years old & 44.0 \\
Education level & Hold years older & 22.1 \\
\hline \multirow{3}{*}{ Annual household } & Hold a master degree & 40.4 \\
income & Less than $\$ 40,000$ & 56.9 \\
& \$40,000 and $\$ 60,000$ & 11.9 \\
& \$60,000 and $\$ 80,000$ & 16.5 \\
& Above $\$ 80,000$ & 32.1 \\
& 5 years of less & 39.4 \\
\hline \multirow{2}{*}{ \# of Working } & 6-15 years & 22.0 \\
Experiences & 16-25 years & 26.5 \\
& More than 26 years & 11.9 \\
\hline
\end{tabular}

Table 2: Component Matrix 1

\begin{tabular}{|c|c|c|c|c|}
\hline \multirow{2}{*}{ Factors } & \multicolumn{4}{|c|}{ Components } \\
\cline { 2 - 5 } & $\mathbf{1}$ & $\mathbf{2}$ & $\mathbf{3}$ & $\mathbf{4}$ \\
\hline Mobility Inefficiency 1 & .880 & & & \\
Mobility Inefficiency 2 & .778 & & & \\
Decision Making 1 & & .845 & & \\
Decision Making 2 & & .775 & & \\
Work & & & .849 & \\
System 2 \\
Work \\
System 1 & & & .730 & \\
Development Opportunity & & & & .833 \\
1 & & & & .701 \\
Development Opportunity & & & & \\
2 & & & & \\
\hline
\end{tabular}

Table 3: Component Matrix 2

\begin{tabular}{|c|c|c|}
\hline \multirow{2}{*}{ Factors } & \multicolumn{2}{|c|}{ Components } \\
\cline { 2 - 3 } & $\mathbf{1}$ & $\mathbf{2}$ \\
\hline Build Relationship 1 & .813 & \\
Build Relationship 2 & .780 & \\
Build Trust 2 & & .739 \\
Build Trust 1 & & .738 \\
\hline
\end{tabular}

Table 4: Component Matrix 3

\begin{tabular}{|c|c|c|}
\hline \multirow{2}{*}{ Factors } & \multicolumn{2}{|c|}{ Components } \\
\hline & 1 & 2 \\
\hline Social Infrastructure for Mass Public & .879 & \\
\hline Social Infractructure for Macs Publis & 834 & \\
\hline 2 & .834 & \\
\hline Social Infrastructure for Mass Public & .742 & \\
\hline Social Infrastructure for Youth 1 & & 865. \\
\hline Social Infrastructure for Youth 2 & & .864 \\
\hline
\end{tabular}

Table. 5: Component Matrix 4

\begin{tabular}{|c|c|}
\hline \multirow{2}{*}{ Factors } & Components \\
\cline { 2 - 2 } & $\mathbf{1}$ \\
\hline Social Activity 3 & .861 \\
Social Activity 2 & .835 \\
Social Activity 1 & .754 \\
\hline
\end{tabular}

This study used factor scores for regression analyses. This study checked that there were no multicollinearity. Table 6 presents the results of regression analysis for the effects of working conditions on job dissatisfaction. As Table 6 shows, work system and development opportunity significantly affect job dissatisfaction, while decisionmaking and mobility inefficiency did not significantly affect job dissatisfaction. The result of ANOVA found the model significant at the level of .01 with $F=17.048$ (rsquare $=.391$ ). As shown in Table 6 , hypotheses H1c and H1d were accepted, while hypotheses H1a and H1b were not accepted.

Table 6: Effects of Working Conditions on Job Dissatisfaction

\begin{tabular}{|c|c|}
\hline Variables & $\begin{array}{c}\text { Standardized } \\
\text { Coefficient (Sig) }\end{array}$ \\
\hline $\begin{array}{c}\text { Mobility Inefficiency } \rightarrow \text { Job Dissatisfaction } \\
(\mathrm{H} 1 \mathrm{a})\end{array}$ & 0.032 \\
\hline $\begin{array}{c}\text { Decision-Making } \rightarrow \text { Job Dissatisfaction } \\
(\mathrm{H} 1 \mathrm{~b})\end{array}$ & 0.097 \\
\hline Work System $\rightarrow$ Job Dissatisfaction (1c) & $0.305(* * *)$ \\
\hline $\begin{array}{c}\text { Development Opportunity } \rightarrow \text { Job } \\
\text { Dissatisfaction (H1d) }\end{array}$ & $0.456(* * *)$ \\
\hline
\end{tabular}

*** Significant at 0.01 level (2-tailed)

The study also examined the effects of interactivity in the workplace on job dissatisfaction of relocated employees. As seen in Table 7, the results of regression analysis find the models significant at the .01 level with $F=26.360$ (r-square 
$=.328$ ). Therefore, $\mathrm{H} 2 \mathrm{a}$ and $\mathrm{H} 2 \mathrm{~b}$ were accepted and conclude that building relationship and trust affects job dissatisfaction.

Table 7: Effects of Interactivity on Job Dissatisfaction

\begin{tabular}{|c|c|}
\hline Variables & $\begin{array}{c}\text { Standardized } \\
\text { Coefficient (Sig) }\end{array}$ \\
\hline $\begin{array}{c}\text { Building Relationships } \rightarrow \text { Job } \\
\text { Satisfaction (H2a) }\end{array}$ & $0.369(* * *)$ \\
\hline $\begin{array}{c}\text { Building Trust } \rightarrow \text { Job Satisfaction } \\
(\mathrm{H} 2 \mathrm{~b})\end{array}$ & $0.309(* * *)$ \\
\hline$* * *$ Significant at 0.01 level (2-tailed)
\end{tabular}

Table 8 indicates the outcomes of regression analysis for effects of social infrastructure for mass public and social infrastructure for youth and social activity on life dissatisfaction. The results of ANOVA showed significant at the level of .01 with $F=48.909$ (r-square $=.583$ ). H3a, H3b, and $\mathrm{H} 4$ were accepted to different extents as to how each variable affects life dissatisfaction. Among the proposed variables, social activity had the greatest effect on life dissatisfaction, followed by social infrastructure for mass public and social infrastructure for youth.

Table 8: Effects on Life Dissatisfaction

\begin{tabular}{|c|c|}
\hline Variables & $\begin{array}{c}\text { Standardized } \\
\text { Coefficient (Sig) }\end{array}$ \\
\hline $\begin{array}{c}\text { Social Infrastructure for mass public } \rightarrow \\
\text { Life Dissatisfaction (H3a) }\end{array}$ & $0.370(* * *)$ \\
\hline $\begin{array}{c}\text { Social Infrastructure for youth } \rightarrow \text { Life } \\
\text { Dissatisfaction (H3b) }\end{array}$ & $0.244(* * *)$ \\
\hline $\begin{array}{c}\text { Social activity } \rightarrow \text { Life Dissatisfaction } \\
(\mathrm{H} 4)\end{array}$ & $0.473(* * *)$ \\
\hline
\end{tabular}

*** Significant at 0.01 level (2-tailed)

Table 9: Effects of Job and Life Satisfaction

\begin{tabular}{|c|c|}
\hline Variables & $\begin{array}{c}\text { Standardized } \\
\text { Coefficient (Sig) }\end{array}$ \\
\hline $\begin{array}{c}\text { Job Satisfaction } \rightarrow \text { Life Dissatisfaction } \\
\underset{(\mathrm{H} 5 \mathrm{a})}{ }\end{array}$ & $0.652(* * *)$ \\
\hline $\begin{array}{c}\text { Life Satisfaction } \rightarrow \text { Job Dissatisfaction } \\
(\mathrm{H} 5 \mathrm{~b})\end{array}$ & $0.652(* * *)$ \\
\hline
\end{tabular}

*** Significant at 0.01 level (2-tailed)

Furthermore, the current study found causal relationships between job satisfaction and life satisfaction (Table 9). With regard to the effect of job satisfaction on life satisfaction, the result shows significant at the level of .01 with $F=79.004$ (r-square $=.425)$. In the case of the effect of life satisfaction on job satisfaction, the results of the ANOVA found the models significant at the level of .01 with $F=79.004$ (r-square $=.425)$.

\section{Conclusions}

\subsection{Discussions}

Previous researches on geographical relocation of workplace addressed cases of private companies, while only a few researchers explored the impact of relocation on the employees of public sector and governmental organization. Further, the scope of previous researches on relocation were limited to job satisfaction, while those studies rarely applied to life dissatisfaction. This study applied negative sides of satisfaction for both job and life, particularly in public sector. Therefore, the present study fill the gap by applying government and public sector and adding life dissatisfaction due to relocation.

This study focuses on the determinants of job and life dissatisfaction after relocation and causal relationships between job and life dissatisfaction. Based on the survey data analysis, the findings of this study showed that most of independent variables used in this study significantly affect job and life dissatisfaction, except factors such as mobility inefficiency and decision-making. When it comes to job dissatisfaction, of the working condition variables, negative perception on work system and self-development opportunity were shown to significantly affect job dissatisfaction. Interactivity variables, including lower building relationships and trust, were found to be significantly related to job dissatisfaction.

In regard to life dissatisfaction, social infrastructure variables for mass public and social infrastructure for youth affected life dissatisfaction. The social activity variable was significantly related to life dissatisfaction as well. Among these factors, social activity was most strongly linked to life dissatisfaction followed by the influence of social infrastructure for mass public and social infrastructure for youth. The results also found that job and life dissatisfaction significantly related. Additionally, the study showed that life dissatisfaction could differ based on places people live. The study examined three groups: employees who moved to the new city, people who did not change their residences, and workers who stayed only on weekdays in the new city. According to the analysis, the mean levels of life dissatisfaction were not all equal across groups.

\subsection{Policy and Managerial Implications}

This study pointed to meaningful policy and managerial implications. The results of this study showed that the role 
of government is important for the level of dissatisfaction with both job and life. Previous scholars agreed that the subjective assessment of quality of life is crucial in developing government administration (Poister \& Henry, 1994; Gold \& Wooldridge, 1995; United States Merit Systems Protection Board, 1991). In order to decrease job dissatisfaction, work systems and self-development opportunities should be improved. Based on the analysis, the recent increase in public sector turnover may be due to the rigid work system and underestimation of potential future self-development. While mobility inefficiency did not affect dissatisfaction, a considerable number of respondents felt a lack of communication due to reduced face-to-face meeting even though their organization has encouraged communication through video conferencing. While decision-making did not affect job dissatisfaction, how to make the decisions-making process more efficiently and how to improve the quality of decisions-making by developing policies are significant managerial issue.

Additionally, government should design relocation policy in a way that relocated employees and their families are satisfied with their new physical and psychological environment in a new planned city. The results showed that respondents felt lack of social infrastructure including transportation, education, hospitals, and accessibility to shopping facility more strongly rather than other proposed variables. Among effects on dissatisfaction, the results show that effects of social activity and development opportunity were stronger than other variables. In order to meet the goal of balanced local development and life satisfaction, it is necessary to provide satisfactory residential conditions and better quality social infrastructure for workers with their spouses and youth. Job and life satisfaction will be improved when conditions of relocated environment meet expectation. In fact, previous researches have pointed out that familial consideration is very influential on the intention to move, and as seen in the present study, circumstances for upbringing youth and living environment significantly affect the life satisfaction of employees. There is a need to create a variety of social activities and to build a culture in addition to work.

Government should also consider to develop better policies to improve both job and life satisfaction because a job is not only a means of living, but is also an important part of an individual's life. In Korea, a culture that pursues work-life balance where an individual's work and life are in harmony is getting stronger. With changes in values regarding work and lifestyle diversification, work and life balance has been recognized as a strategy that could result in co-prosperity for both businesses and individuals, as it could improve quality of life to secure a competitive advantage in a corporate position. Given that work and life balance improves employees' satisfaction with their work and loyalty to their job, an organization should introduce and operate a system or program that address other aspects of employees' lives. Some believe that work and life balance divides work from life in a dichotomous way, and furthermore, that work is bad and things other than work are good. However, as indicated from the data analysis, job and life dissatisfaction are closely related to one another, and accordingly, this perspective can increase bilateral conflict. Social policy should be given more attention in terms of achieving higher life satisfaction in a new planned city. This is because newcomers have many basic material and mental needs that need to be met. Better policies to improve government and citizen relationship management should be highlighted in the context of relocation.

\subsection{Limitations and Future Research}

This study has limitations. Future research might consider increased sample size with application of structural equation model. Future research might consider the comparative analysis of the satisfaction level among relocated places. In achieving balanced development, the results of comparative analysis would be able to draw useful implications to provide possible strategies to reach higher levels of satisfaction for relocation.

\section{Reference}

Adkins, C. L., Ravlin, E. C., \& Meglino, B. M. (1996). Value Congruence between Co-workers and its Relationship to Work Outcomes. Group \& Organization Management, 21(4), 439460.

Bae, J. (2005). Public Sector Relocation and Balanced Regional Development: A Case of French Experience. The Korean Association of Regional Geographers, 11(1), 72-82.

Bass, B. M., \& Bass, R. (1976). Concern for the Environment: Implications for Industrial and Organizational Psychology. American Psychology, 31(2), 158-166.

Baldwin, J. N., \& Farley, Q. A. (1991). Comparing the Public and Private Sectors in the United States: A Review of the Empirical Literature. In A. Farazmand (Ed.), Handbook of Comparative and Development Public Administration, 27-39. NY: Marcel Dekker.

Basley, T., \& Coate, S. (1997). An Economic Model of Representative Democracy. The Quarterly Journal of Economics, 112(1), 85-114.

Biderman, A. D., \& Drury, T. F. (Eds.) (1976). Measuring Work Quality for Social Reporting. NY: Wiley.

Brett, J. M. (1980). The Effects of Job Transfer on Employees and Their Families In: Cooper, C. L. and Payne, R. (Eds), Current Concerns in Occupational Stress, Wiley, Chichester.

Brett J. M., \& Reilly, A. H. (1988). On the Road Again: Predicting the Job Transfer Decision. Journal of Applied Psychology, 73(4), 614-620.

Brewer, G. A., \& Selden, S. C. (2000). Why Elephants Gallop: 
Assessing and Predicting Organizational Performance in Federal Agencies. Journal of Public Administration Research and Theory, 10(4), 685-712.

Carless, S. A. (2005). Person-job fit versus Person-organization fit as Predictors of Organizational Attraction and Job Acceptance Intentions: A Longitudinal Study. Journal of Occupational and Organizational Psychology, 78(3), 411-429.

Chen, C., Hsieh, C., \& Chen, D. (2014). Fostering Public Service Motivation through Workplace Trust: Evidence from Public Managers in Taiwan. Public Administration, 92(4), 954-973.

Clark, A. E., Georgellis, Y., \& Sanfey, P. (1998). Job Satisfaction, Wage Changes and Quits: Evidence from German Panel Data. Research in Labor Economics, 17, 88-101.

Cotton, J., \& Tuttle, J. (1986). Employee Turnover: A MetaAnalysis and Review with Implications for Research. The Academy of Management Review, 11(1), 55-70.

Cotton, J., \& Majchrzak, A. (1990). Psychological Predictors of Geographical Relocation: Case Study of a Plant Shutdown. Journal of Business and Psychology, 4(3), 375-384.

Diener, E. (1994). Assessing Subjective Well-being: Progress and Opportunities. Social Indicators Research, 31(2), 103-157.

DeSantis, V. S., \& Durst, S. L. (1996). Comparing Job Satisfaction among Public-and Private-Sector Employees. The American Review of Public Administration, 26(3), 327-343.

Dohrenwend, B. S., \& Dohrenwend, B. P. (1974). Stressful Life Events: Their Nature and Effects, Wiley: New York.

Edwards. J. R. (1991). Person-job Fit: A Conceptual Integration, Literature Review, and Methodological Critique. In C. L. Cooper \& I. T. Robertson (Eds.) International Review of Industrial and Organizational Psychology, 283-357, New York, NY: John Wiley.

Eby, L. T., \& Dematteo, J. S. (2000). When the Type of Move Matters: Employee Outcomes under Various Relocation Situations. Journal of Organizational Behavior. 21, 677-687

Eby, L. T., \& Russell, J. E. A. (2000). Predictors of Employee Willingness to Relocate for the Firm. Journal of Vocational Behavior. 57(1), 42-61.

Fahey, T., \& E. Smyth (2004). Do Subjective Indicators Measure Welfare? Evidence from 33 European Societies', European Societies, 6(1), 5-27.

Feldman, D. C., \& Brett, J. M. (1983). Coping with New Jobs: A Comparative Study of New Hires and Job Changers. Academy of Management Journal, 26(2), 258-272.

Filiz, Z. (2014). An Analysis of the level of Job Satisfaction and Life satisfaction of the Academic Staff. Social Indications Research, 116(3), 793-808

Fisher, C., \& Shaw, J. (1994). Relocation Attitudes and Adjustment: A Longitudinal Study. Journal of Organizational Behavior, 15(3), 209-224.

Fox, S., \& Krausz, M. (1987). Correlates of Relocation Intention and Emotional Responses to an Israeli Plant Relocation. Journal of Occupational Behaviour, 8(4), 325-338.

Gilmer, B. V. H. (1971). Industrial and organizational psychology. Mc Graw-Hill: NY.

Gold. M., \& Wooldridge, J. (1995). Surveying Consumer Satisfaction to assess Managed-Care Quality: Current Practices. Health Care Financing Review, 16(4), 155-173.

Gottholmseder, G., Nowotny, K., Pruckner, G. J., \& Theurl, E. (2009). Stress Perception and Commuting. Health Economics,
$18(5), 559-576$.

Guarnieri, S., Smorti, M., \& Tani, F. (2015). Attachment Relationships and Life Satisfaction During Emerging Adulthood. Social indicators Research, 121(3), 833-847.

Halachmi, A. (1997). Government Reforms and Public Productivity: do We have All the Answers? Work Study, 46(7), 233-245.

Inglehart, R. F. (2010). Faith and Freedom: Traditional and Modern Ways to Happiness. 351-97 in International Difference in Well-Being, edited by E. Diener, J. F. Helliwell, and D. Kahneman, New York: Oxford University Press.

Janis, I. L., \& Mann, L. (1977). Decision Making, The Free Press, NY.

Ju, S. J. (2003). Lessons from the Foreign Experience of Relocating the Capital Function or Public Agencies. Journal of the Korean Regional Science Association. 19(2), 187-208

Judge, T. A., Thoresen, C. J., Bono, J. E., \& Patton, G. K. (2001). The Job Satisfaction-Job Performance Relationship: A Qualitative and Quantitative Review. Psychological Bulletin, 127(3), 376-407.

Kim, T (2015). Public Sector Relocation and Balanced Regional Development: A Case of French Experience. Gyeongg, Korea Research Institute for Human Settlements.

Kim, Y. (2019). The Effects of Attractiveness of Service Employee's on Interpersonal Trust, Satisfaction, and Loyalty. The International Journal of Industrial Distribution \& Business, 10(10), 23-34.

Krause, N. M. (2008). Aging in the Church: How Social Relationships affect Health. West Conshohocken, PA: Templeton Foundation Press.

Kristof, A. L. (1996). Person-organization Fit: An Integrative Review of its Conceptualizations, Measurement, and Implications. Personnel Psychology, 49(1), 1-49.

Kim, S., \& Kim, D. (2012). Does Government make People Happy? Exploring New Research Directions for Governments Roles in Happiness. Journal of Happiness Studies, 13(5), 875899.

Kim, J. Y., \& Lee, D. G. (2017). An Inquiry into the Real Aspects of Policy Making Process in the Ministries moved to Sejong City. Korea Institute of Public Administration

Kolar, D. E. (1977). A Study of Selected Variables related to Employee Relocation. Doctoral Dissertation, Illinois Institute of Technology.

Krings, B-J., L. Nierling, M. P., \& Piersanti M. (2009). Working time, Gender and Work-Life Balance, Leuven: HIVA

Lim, C., \& Putnam, R. D. (2010). Religion, Social Networks, and Life Satisfaction. American Sociological Review, 75(6), 914933

London, M., \& Smither, J. W. (1999). Empowered SelfDevelopment and Continuous Learning. Human Resource Management, 38(1), 3-15.

Lyubomirsky, S., King, L., \& Diener, E. (2005). The Benefits of Frequent Positive Effect: Does Happiness lead to Success? Psychological Bulletin, 131(6), 803-855.

Ma, C. Q., \& Huebner, E. S. (2008). Attachment Relationships and Adolescents' Life Satisfaction: Some Relationships Matter more to Girls than Boys. Psychology in the Schools, 45(2), 177-190.

Matiaske, W., \& Grözinger, G. (2011). Introduction: Job 
Satisfaction Revisited. Management Revue, 22(1), 5-7.

Mowday, R. T., Porter, L. W., \& Steer, R. M. (1982). Employeeorganization Linkages: The Psychology of Commitment, Absenteeism and Turnover, New York: Academic Press.

Naumann. E. (1993). Organizational Predictors of Expatriate Job Satisfaction. Journal of International Business Studies, 24(1), 61-80.

Nguyen, M. H., \& Khoa, B. T. (2019). Customer Electronic Loyalty towards Online Business: The Role of Online Trust, Perceived Mental Benefits and Hedonic Value. Journal of Distribution Science, 17(12), 81-93.

Nickerson, A., \& Nagle, R. J. (2005). Parent and Peer Attachment in Late Childhood and Early Adolescence. Journal of Early Adolescence, 25, 223-249.

Okulicz-Kozaryn, A. (2013). City Llife: Ranking (Livability) verse Perceptions (Satisfaction). Social Indicators Research. $110(2), 433-451$.

Ott, J. C. (2011). Government and happiness in 130 nations: Good Governance fosters Higher Level and More Equality of Happiness. Social Indicators Research, 114(2), 607-619.

Park, Y. H., \& Kim, C. H. (2002). Locational Analysis and Spatial Reorganization Strategies of Central Management Function in Korea. Gyeongg, Korea Research Institute for Human Settlements.

Paterson, J. E., Field, J., \& Pryor, J. (1994). Adolescents' Perceptions of their Attachment Relationships with their Mothers, Fathers, and Friends. Journal of Youth and Adolescence, 23(5), 579-600.

Poister, T. H., \& Henry, G. T. (1994). Citizen Ratings of Public and Private Service Quality; A Comparative Perspective. Public Administration Review, 54(2), 155-160.

Pollert, A. (1991). The Orthodoxy of Flexibility. In A. Pollert (Ed.), Farewell to Flexibility? Oxford: Basil Blackwell.

Rainey, H. G. (1983). Public Agencies and Private Firms Incentive Structures, Goals, and Individual Roles. Administration \& Society, 15(2), 207-242.

Rossman, V. (2017). Capital Cities: Varieties and Patterns of Development and Relocation. London: Routledge.

Steel, B. S., \& Warner, R. L. (1990). Job Satisfaction among Early Labor Force Participants: Unexpected Outcomes in Public and Private Sector Comparisons. Review of Public Personnel Administration, 10(3), 4-22.

Schaeffer M, Street S, Singer J, \& Baum A. (1988). Effects of Control on the Stress Reactions of Commuters. Journal of Applied Social Psychology, 18(11), 944-957.

Spector, M. D., \& Jones, G. E. (2004). Trust in the Workplace: Factors affecting Trust Formation between Team Members. The Journal of Social Psychology, 144(3), 311-321.

Summers, T. P., \& Holcombe, J. S. (1990). The Effect of offers to Relocate on Attitudes of Departed Employees following a
Merger. Journal of Social Behavior and Personality, 5(5), 323-326.

Sirgy, M. J., \& Cornwell, T. (2002). How Neighborhood Features Affect Quality of Life, Social Indicators Research, 59(1), 79114

The Economist (2011). Liveable Cities Challenges and Opportunities for Policymakers. Economist Intelligence Unit, November.

The Economist (2019). Why Governments Move Civil Servants out of National Capitals. April.

Thompson, S. C. (1981). 'Will it Hurt Less If I can Control It? A Complex Answer to a Simple Question. Psychological Bulletin, 90(1), 89-101.

Turban, D. B., Campion, J. E., \& Eyring, A. R. (1992). Factors Relating to Relocation Decisions of Research and Development Employees. Journal of Vocational Behavior, 41(2), 183-199.

Terry, T., \& Huebner, E. S. (1995). The Relationship between Self-concept and Life Satisfaction in Children, Social Indicators Research, 35(1), 39-52.

United States Merit Systems Protection Board (1991). Balancing Work Responsibilities and Family Needs: The Federal Civil Service Response.

Veenhoven, R. (1996). Developments in Satisfaction-Research. Social Indicators Research, 37(1), 1-46.

Wang, Y. D., Yang, C., \& Wang, K. Y. (2012). Comparing Public and Private Employees' Job Satisfaction and Turnover. Public Personnel Management, 41(3), 557-573.

Wener, R. E., Evans, G. W, Phillips, D., \& Nadler, N. (2003). Running for the 7:45: the effects of public transit improvements on commuter stress. Transportation, 30(2), 203-220.

Wei, M., Liao, K., Ku, T., \& Shaffer, P. (2011). Attachment, Selfcompassion, Empathy, and Subjective Well-being among College Students and Community Adults. Journal of Personality, 79(1), 191-221.

Werbel, J. D., \& Johnson, D. J. (2001). The Use of Person Group fit for Employment Selection: A Missing Link in Personenvironment Fit. Human Resource Management, 40(3), 227240.

Wong, C., Wong, K., \& Mok, B. (2006). Subjective Well-Being, Societal Condition and Social Policy: The Case Study of a Rich Chinese Society. Social Indicators Research, 78(3), 405428.

Wiggins, R. L., \& Steade, R. D., (1976). Job Satisfaction as a Social Concern. The Academy of Management Review, 1(4), 48-55.

Wright, B. E., \& Davis, B. S. (2003), Job Satisfaction in the Public Sector: The Role of the Work Environment. American Review of Public Administration, 33(1), 70-90. 